\title{
41919
}

\section{Postcards from Brazil: o avesso da paisagem e a vida do presente}

Fábio Gatti \& Cassandra Barteló

\section{Resumo:}

O cenário político brasileiro vem sofrendo mudanças nos últimos anos. Em 2016, a presidência da república sofre um golpe que culmina na destituição da então presidente Dilma Rous-seff (PTPartido dos trabalhadores). Com base nessa nova configuração política, o artista Gilvan Barreto realiza o trabalho Postcards from Brazil: cicatrizes da paisagem. Sensível aos desencadeamentos do período e, sobretudo, atento à ascensão da extrema direita, ele recorre à arte a fim de recuperar poeticamente os horrores da ditadura militar brasileira. O presente artigo apresenta uma análise de Postcards, tendo como base cinco eixos: o postal, o arquivo, o documento, a fotografia e a paisagem. Para tanto, toma-se como alicerce reflexivo a necropolítica de Achile Mbembe, o pensamento sobre o povo brasileiro de Darcy Ribeiro e a violência colonial em Franz Fanon e sua aproximação com a política em Luís Felipe Miguel; as discussões sobre documentação, arquivo e fotografia em Joan Fontcuberta, Boris Kossoy, Michael Buckland, Christian Berger e Jessica Santone, Serge Tisseron e Hall Foster; a questão da paisagem pela geografia compreensiva de Milton Santos e pelos argumentos de William J. T. Mitchell. Outros textos, assim como a entrevista feita com Gilvan Barreto, servem de sustento para tal conversação e ajudam a entender o avesso da paisagem e a vida do presente do Brasil.

Palavras-chave: Fotografia; Arte; Ditadura militar brasileira; Paisagem; Documento.

\section{Abstract:}

The Brazilian political scene has undergone a huge change since 2013. A soft coup for removing former President DilmaRousseff (PT) took place in 2016. Based on this configuration, Gilvan Barreto carried out the work Postcards from Brazil: scars of the landscape. Sensible to the 
triggering of this period and, in particular, aware of the growing discourses from far right, he invoke art and poetically recovers the horrors of the Brazilian military dictatorship. This article presents an analysis of Postcards, based on five axes: the postcard, the archive, the document, the photograph and the landscape. For this purpose, it takes as a reflective foundation the necropolitics from Achile Mbembe, the thinking about Brazilian people from Darcy Ribeiro and the colonial violence in Franz Fanon and its approach to politics in Luís Felipe Miguel, the discussions over documentation, archive and photography in Joan Fontcuberta, Boris Kossoy, Michael Buckland, Christian Berger and Jessica Santone. Serge Tisseron and Hall Foster, the question of landscape by the comprehensive geography from Milton Santos and the arguments of William J. T. Mitchell, are taken as reflective foundations for this. Other texts serve as support for such a conversation as well as the interview with GilvanBarreto and help to unders-tand the averse of the landscape and the life in the present of Brazil.

Keywords: Photography; Art; Brazilian militar dictatorship; Landscape; Document.

No Amazonas, no Araguaia iá, iá

$\mathrm{Na}$ Baixada Fluminense Mato Grosso, Minas Gerais E no Nordeste tudo em paz

Na morte eu descanso

Mas o sangue anda solto Manchando os papéis, documentos fiéis

Ao descanso do patrão

Que país é esse?

Renato Russo, Que país é este?, 1978

\section{Introdução}

Darcy Ribeiro (1995: 30) diz parecer impossível reconstituir de forma integral o processo colonizador, uma vez que existe unicamente o testemunho dos protagonistas, todos eles invasores. Menciona ainda a supressão das vozes de índios e negros, subalternos impossibilitados de expor suas próprias falas, tal qual evidencia Spivak (2010: 20) quando comenta sobre o modo como o sujeito do "Terceiro Mundo é representado no discurso ocidental", denunciando, assim, a violência epistemológica à qual ele foi submetido. Vista como classe inferior e, portanto, exposta a todos os tipos de violação e cerceamento de direitos, a população indígena foi quase totalmente dizimada desde as exortações de Pero Vaz de Caminha ao Rei Dom Manoel, expressas em uma carta 
de 1500, na qual afirmava que o único bem possível a "essa gente" seria salvá-la. Uma salvação advinda da Igreja, "uma Igreja de Brancos, uma igreja de estrangeiros. Não chama o homem colonizado para a via de Deus mas para a via do Branco, a via do patrão, a via do opressor" (Fanon, 1968: 31).

Qualquer semelhança com a realidade brasileira do século XXI não é mera coincidência: ao contrário, é a evidência de uma violência estrutural que "permanece sendo o coração oculto da política" (Miguel, 2014: 29). Nesse sentido, é urgente entender a premissa de Ribeiro (1995: 204) ao declarar que "a tarefa das novas gerações de brasileiros é tomar este país em suas mãos para fazer dele o que há de ser, uma das nações mais progressistas, justas e prósperas da terra".

A prática artística de Barreto, ao produzir seus Postcards from Brazil: cicatrizes da paisagem, aproxima-se tanto da afirmação de Ribeiro quanto do pensamento de Hélio Oiticica. Em Esquema Geral da Nova Objetividade, de 1967, Oiticica (2009) trata, no item 4, da tomada de posição em relação a problemas políticos, sociais e éticos, requerendo um posicionamento crítico do artista, cuja existência deve ser participativa em relação à sua época e a seu povo.

Composto de 35 postais, o trabalho de Barreto propõe apresentar um mapa das paisagens brasileiras, tanto as naturais quanto as político-sociais. As primeiras são apresentadas como cenários para os crimes da ditadura militar brasileira (1964-1985), nas quais centenas de corpos de pessoas assassinadas durante esse regime foram ocultados; e as segundas enquanto cenas da vida desse país supostamente democrático, cujas posturas políticas e governo atuais revelam retrocesso, fortalecido por discursos do poder, como na declaração feita pelo Presidente do Superior Tribunal Federal, o ministro Dias Toffoli, ao se referir à Ditadura não como Golpe Militar, mas sim 'movimento de 1964' (Pessoa, 2018).

O Brasil é um campo de morte ${ }^{1}$ que, desde seu 'descobrimento', só faz manter a violência herdada das estruturas coloniais, seja pela criação da ideia de raça (Quijano, 2005), seja pela necropolítica ${ }^{2}$ atuante. Morrer é algo ordinário em um país como o Brasil

\footnotetext{
${ }^{1}$ Essa categoria aparece em Mbembe (2017) para discutir o modo pelo qual a vida e o corpo estão inscritos no poder. É uma figura para pensar a violência estrutural, a soberania e a aniquilação da vida e dos corpos de pessoas que fogem à regra do sujeito padrão.

${ }^{2}$ As noções de necropolítica e necropoder (esse termo aparecerá no final de nosso texto) são reflexões de Mbembe, discutidas no ensaio homônimo ao primeiro termo. O autor amplia os indicadores de biopolítica e biopoder foucaultianos, estabelecendo uma diferença crucial: do sistema de governança que controlava a vida e as corporalidades passa-se a outro, no qual não se trata apenas de controlar modos de existência e corporais e sim de definir quem pode e quem não pode morrer ou, de outro modo, quem merece ou não estar vivo. As quatro perguntas elaboradas por Mbembe no início do ensaio são respondidas ao longo de
} 
e, ao contrário do que ocorre em Ensaio sobre a Cegueira, de José Saramago, não há estado de exceção nem de calamidade, e sim de normalidade: mais de 4 milhões de índios assassinados desde o século XV; cerca de 600 mil negros mortos no trajeto África-Brasil, dos quais 200 mil no percurso até a Bahia, e sem contar os que foram executados depois de desembarcados; 3,5 milhões de pessoas mortas por falta de água na seca que durou sete anos na década de 1980, no Nordeste brasileiro; além das recorrentes chacinas em favelas brasileiras, fruto da atuação de milícias e de departamentos policiais 'especializados' em combater o 'crime'.

"É um recorte dos tempos e dos espaços, do visível e do invisível, da palavra e do ruído que define ao mesmo tempo o lugar e o que está em jogo na política como forma de experiência" (Rancière, 2005: 16), que permite uma possível reflexão acerca dos Postcards from Brazil e dos artifícios precisos utilizados na construção da estratégia artística de Barreto: o postal, o arquivo, o documento, a fotografia, a paisagem.

\section{Os artifícios de Barreto na elaboração dos Postcards}

Barreto resgata a história recente de um país torturado e as dores de uma das épocas mais sombrias do Brasil, que, até 2014, não tinha outra versão senão a do Exército Brasileiro e seus oficiais, isto é, uma perspectiva cuja "expressão máxima da soberania reside, em grande medida, no poder e na capacidade de ditar quem pode viver e quem deve morrer" (Mbembe, 2016: 123). Com a instituição da Comissão Nacional da Verdade (CNV), em 2011, durante o governo de Dilma Rousseff - ela também uma vítima das torturas praticadas nesse período -, os crimes cometidos pela ditadura foram apurados e publicados em relatórios trazidos a público em 2014.

A ação artística de Barreto revela a urgência em rever os passos dados pela Nação até o presente: um amplo presente, parafraseando Gumbrecht (2015), em que o passado foi deixado para trás e o futuro se apresenta como ameaça e não mais um espaço aberto a possibilidades; um presente de temporalidades simultâneas, não mais históricas; um presente sem contornos definidos, sempre em expansão. Com o subtítulo Cicatrizes da paisagem, cada cartão-postal faz referência à memória dos que foram assassinados quando lutavam pela liberdade em um período de violenta repressão. Cada recorte nas imagens representa o corpo de uma pessoa brutalmente morta e descartada em um desses espaços naturais.

"Por mais que a violência política esteja presente, que faça parte dos embates cotidianos, ela é sempre marcada com os signos da excepcionalidade, do desvio.

suas reflexões e sinalizam a urgência de questionar o lugar concedido à vida, à morte e ao corpo humano dentro do atual sistema político. 
Portanto, precisa ser incorporada nas matrizes que elaboramos para pensar a política e suas possibilidades" (Miguel, 2014: 29). Lutar contra essa excepcionalidade é uma das tônicas dos Postcards de Barreto, dada a incorporação dessas lembranças do presente (porque não exclusivas ao passado) pelo uso do formato cartão-postal, uma clara referência à arte postal, isto é, ao modo como muitos artistas enfrentaram a ditadura brasileira criando "uma rede democrática e irrestrita de comunicação, numa época em que todas as formas de comunicação haviam sido interrompidas ou eram cerceadas" (Lopes, 2014: 2659) ${ }^{3}$. Além disso, a criação do formato postal foi uma enorme revolução cultural: um momento em que as imagens, fossem elas advindas do mundo real ou do universo fantasioso, do particular ou do coletivo, se tornaram meio de comunicação em massa (Kossoy, 2016). Correia (2013: 47) também recorre à história do postal para ressaltar como este se tornou parte de nossa cultura visual:

meio de comunicação marginal, proveniente do séc. XIX, o postal ilustrado propiciava-se a repensar as complexidades da circulação de imagens e a repercussão destas na perceção, na imaginação, na memória e na socialidade contemporâneas. Desencadeada em grande parte pelo aparecimento da fotografia no séc. XIX e continuamente metamorfoseada pelo conseguinte progresso das tecnologias da imagem e da comunicação que culminariam no aparecimento do digital e na vulgarização do ciberespaço no séc. XXI, a cultura visual encontrava no postal ilustrado um exemplo dos processos de continuidade e de rutura da mesma.

É salutar compreender que a chegada da moda do postal ao Brasil se deu, primeiramente, pela classe mais abastada e pelas imposições comerciais gestadas na Europa, voltadas à produção de postais para colecionismo com edições sofisticadas, conforme explica Kossoy (2016). Em um segundo momento, em especial a partir da década de 1960, a circulação dos postais já não era mais restrita apenas à elite econômica. Quanto à temática, os cartões-postais, em geral, apresentavam paisagens - ruas, edifícios e monumentos históricos - e os costumes dos povos.

As imagens mentais do chamado mundo real e as do universo da fantasia individual e coletiva se tornam finalmente acessíveis para a grande massa. Um mundo portátil, fartamente ilustrado, passível de ser colecionado, construído de uma sucessão infindável de temas vem finalmente saciar o imaginário popular. (Kossoy, 2016: 61-63)

\footnotetext{
${ }^{3}$ A arte postal ou Mail Art tem seu início no final da década de 1950, sendo reconhecida como tal em meados dos anos 1960. Robert Filliou se referiu à abertura comunicativa promovida pela arte postal do período como The Eternal Network. Era o primeiro momento em que as produções artísticas por correspondência via correio se consolidaram. Para nossos argumentos, interessa manter o foco na circulação e na distribuição desse tipo de produção no período que compreende a ditadura militar brasileira. Porém, para se ter uma visão mais completa sobre a Mail Art e suas reverberações, sugere-se a leitura do livro Eternal Network: a mail art anthology, editado por Chuck Welch (Welch, 1995).
} 
Para além da popularização dos postais, é importante relembrar a discussão requerida pela arte contemporânea acerca do valor e do lugar da arte. Logo, usar os Correios para deslegitimar a lógica valorativa e institucionalizada do circuito da arte foi a subversão da arte postal dos anos 1960-70 (Schedler, 2016). Nesse sentido, a arte postal foi entendida como uma produção política, contestadora e subversiva, rompendo com os preceitos do circuito da arte e driblando o silenciamento imposto pela ditadura militar brasileira. Ao tratar das intervenções artísticas no início do século XX, Correia (2013: 162) aponta que "o postal ilustrado não exerceu somente um singular papel de divulgação de obras entre o público comum mas também foi um suporte de ligação entre os artistas da época".

Entretanto, a arte postal - assim como outras práticas efêmeras adotadas como estratégias artísticas nesse período - era deliberadamente ausente de autoria, visto que, "temendo a perseguição, muitas vezes exercida de forma arbitrária e sem aviso, estes artistas se esforçavam para não deixar vestígios de autoria em suas obras" (Carliman, 2013: 6).

Já a prática de Barreto, embora diretamente conectada com o período ditatorial no Brasil, não é uma ação de subversão, como na arte postal, nem de luta contra a arte enquanto instituição e tampouco de destituição de autoria. Ao contrário, ele usa os Correios como um modo de recuperar esse universo sombrio e incerto do regime ditatorial, em um momento em que as correspondências se dão virtualmente, seja pelo envio de e-mails ou mensagens diretas por Facebook, Instagram e Whatsapp. Trata-se, então, de uma retomada dos modos primordiais de comunicação: a correspondência física.

O artista ressalta que sua intenção é jogar com os clichês ufanistas presentes na história do Brasil e mostrar o outro lado do Florão da América: o avesso da paisagem turística e a vida de milhões de brasileiros, tanto a dos sobreviventes da época ditatorial quanto a dos mortos-vivos, como descreve Mbembe em sua Necropolítica ${ }^{4}$. Postcards from Brazil é "um grito contra a onda reacionária", mas não apenas isso ${ }^{5}$. É um alerta a esse

\footnotetext{
4 Para Mbembe (2016: 146), as noções de necropolítica e necropoder promovem a criação de "formas novas e únicas de existência social, nas quais vastas populações são submetidas a condições de vida que Ihes conferem o status de "mortos-vivos"."

${ }^{5} \mathrm{O}$ trabalho começou justamente no período do afastamento da presidenta eleita Dilma Rousseff (PT), em 2016, ocorrido por meio de um polêmico impeachment cuja declaração feita, à época, pelo então Deputado Jair Bolsonaro - atual presidente do país - homenageou o coronel Carlos Alberto Brilhante Ustra, "o pavor de Dilma Rousseff"; coronel que comandou sessões de tortura contra a própria Dilma (Barba, 2018).O afastamento de Dilma Rousseff da presidência se deu em função das chamadas 'pedaladas fiscais', manobras contábeis ilícitas realizadas para assegurar ao mercado que o governo apresenta gastos
} 
estado de violência que se mantém aceso. É sobre o fogo não extinto da ditadura militar: "Não à toa estamos nesta situação atual. Postcards é inclusive uma ação artística. Imprimi os postais, criei carimbos e mandei essas lembranças pelos Correios. É o passado se fazendo presente. A chama reacionária e fascista está acesa" (Barreto, 2018).

Nos anos1960, muitos artistas brasileiros estavam envolvidos com a produção da arte conceitual, como Cildo Meirelles e Paulo Bruscky, este último com uma enorme atividade de arte postal, ou como ele próprio denomina: 'Arte Correio'. Há uma conexão com o tema da violência, também explorado em inúmeros trabalhos conceituais (Schedler, 2016). Para Bruscky (2009: 375-374), na Arte Correio dois pontos são importantes: primeiro, usar o correio "como veículo, como meio e como fim, fazendo parte/sendo a própria obra" e, segundo, retomar "suas principais funções: a informação, o protesto e a denúncia", necessárias à sua existência, circulação e visualização. Barreto, em sua proposta, aproxima-se somente deste último produzindo uma obra que questiona a informação ao mesmo tempo em que corporifica um protesto e apresenta uma denúncia.

Pensar a informação nos conduz, portanto, à teoria do documento e à discussão sobre a documentação, assim como à ideia de arquivo, presentes em Postcards from Brazil, que, de certo modo, pode "ser considerado um trabalho documental" (Barreto, 2018), porém não exclusivamente. Mas, o que pode ser um documento? Como verbo, isto é, documentar, entende-se como tornar evidente e, como substantivo, algo com o qual você aprende, segundo Buckland (2013: 224). Uma crítica importante feita por ele reside no fato de que:

está na moda falar de uma nova ou emergente 'sociedade da informação', mas toda sociedade é uma 'sociedade da informação' e sempre será porque todas as comunidades, humana ou animal, são formadas pela comunicação, interação e colaboração. [...] Não podem ser 'sociedades da não-informação!' 6 (Buckland, 2013: 224)

A tese desse autor é que se vive em uma 'sociedade do documento', uma vez que são criadas, usadas e multiplicadas as fontes de consulta, assim como ampliado o

equilibrados. A acusação se deu por crime de responsabilidade. Para mais informações, sugere-se a leitura da coluna de Luiz Ruffato no El País (Ruffato, 2016, 1 de setembro). Atualmente, reportagens da 'Vaza Jato', uma analogia à operação Lava Jato da Polícia Federal que levou o ex-presidente Lula à prisão, produzidas com base em áudios obtidos pelo The Intercept Brasil, demonstram a prática de um golpe de estado contra Rousseff (Heidar et al, 2019, 18 de outubro).

${ }^{6}$ No original: "It has been fashionable to speak of a new or emerging "information society" but every society is an "information society" and always was because all communities, both human and animal, are formed by communication, interaction and collaboration. [...] There cannot be a "non-information society"!" 
entendimento acerca do que é (e o que pode ser) um documento. É preciso delinear que documento foi um elemento bastante importante à arte contemporânea, sobretudo a partir da década de1960, quando a fronteira entre documento e trabalho artístico se dissolveu. Além disso, a produção artística desse período não apenas usou os documentos, como os criou e, ainda, inventou técnicas para sua administração: colecionismo, arquivamento, organização, contextualização e manipulação (Berger \& Santone, 2016).

Dois aspetos são interessantes para pensar os Postcards from Brazil: de um lado, a relação com a evidência do documento, fortemente vinculada à fotografia $e$, de outro, a noção de invenção que associa realidade e imaginário. A fotografia, que surge permeada pelo ideário moderno, pela noção de progresso cumulativo, advindo da ciência, integra o pensamento sobre as fontes documentais. Assim, a fotografia, enquanto espelho da realidade, participa dos mesmos circuitos que o texto como documento no século XIX. Por isso, é possível concordar com o que Berger e Santone (2016: 203) afirmam a respeito de documentos e arquivos: "ambos são repositórios das verdades modernas, consultados para melhorar nossa compreensão sobre investigações forenses, estudos populacionais quali e quantitativos, saúde pública, e psicologias individuais e coletivas ${ }^{7 "}$.

Considera-se a fotografia algo parecido com a escrita, ou seja, com a linguagem escrita. Porém sua aparição produziu-se quando os deuses já tinham abandonado os homens e o espírito positivista imperava sobre o mundo moderno. Contudo, no seu caso, os anátemas que recebia ainda provinham do conflito entre uma tradição oral (entendida como aquilo que é supostamente natural) e uma tradição "literária" (entendida como aquilo que é filtrado por convenções culturais e pela tecnologia). (Fontcuberta, 1996: 9)

Sob essa ótica, Tisseron (2009) assinala que a fotografia apareceu subjugada à cultura do livro e, por isso, foi forçadamente colocada ao lado da verdade, do espírito positivista. Todavia, desde seu surgimento - e é o que nos mostra a história das imagens fotográficas e não os escritos sobre essas imagens -, a fotografia apresenta uma "realidade mista" em que o real e a ficção se encontram mutuamente. Assim também ocorre em Postcards from Brazil, cuja visualidade não se trata exclusivamente do real e tampouco de documento, mas de invenção, visto que a produção artística, de acordo com Stiegler (2006: 36), é uma mediadora ímpar da experiência sensível, capaz de

\footnotetext{
${ }^{7}$ No original: "Both were repositories of modern truths, consulted for improving our understanding of criminal forensics, qualitative and quantitative studies of populations, public health, and collective or personal psychologies."
} 
dilatar o campo da sensibilidade e intensificar a singularidade dos indivíduos diante do mundo, dos fatos, da vida.

No que se refere ao arquivo, é válido reconhecer a existência de um 'impulso arquivístico' no trabalho de Barreto, tal qual Foster percebeu em No Ghost Just Shell, de Pierre Huyghe e Philippe Parreno:

o trabalho em questão é arquivístico uma vez que não se baseia apenas em arquivos informais, mas também os produz, de modo a ressaltar a natureza de todos os materiais de arquivo como encontrados e construídos, fatuais e fictícios, públicos e privados ${ }^{8}$. (Foster, 2004: 5)

Nessa lógica, Barreto, nas paisagens criadas na série de postais, recorre a fontes documentais fatuais e disponíveis ao acesso público, como bancos de imagens de órgãos oficiais de turismo - mais especificamente da Empresa Brasileira de Turismo (Embratur), criada em 1966, no auge do regime ditatorial com o objetivo de melhorar a imagem do país no exterior e incentivar o turismo - para montar o que chama de "uma espécie de atlas da violência da ditadura militar no Brasil" (Barreto, 2018). As imagens, usadas para esconder a violência da ditadura, contrariamente, ganharam visibilidade nas mãos do artista. Em vez de expor as belezas naturais do país, como objetivava na época o regime, a obra traz à tona as cicatrizes deixadas pelo Golpe de 64, em meio ao que é considerado um novo golpe (ver nota de rodapé $n$ ํ5), que vem sendo denunciado ao mundo por entidades e intelectuais.

Essa prática arquivística, segundo Foster (2004), participa de uma pré-produção como também de uma pós-produção: Barreto faz, claramente, esse percurso de pré e pósprodução ao procurar nos arquivos os documentos requeridos à sua intenção artística, editando-os, selecionando-os e, posteriormente, adicionando e tratando as informações eleitas até, por fim, realizar as incisões, as rasgaduras: "a imagem em contato com o real nos revela ou nos oferece univocamente a verdade dessa realidade? Claro que não. [...] A imagem arde em seu contato com o real" (Didi-Huberman, 2012: 208). Essa ardência é uma vibração, um movimento, ela arde para se manter viva ao tempo em que reacende a chama dos eventos desse amplo presente.

Arquivar, ou seja, inventariar o real foi uma das grandes funções da fotografiadocumento, que, segundo Rouillè (2009), perfez um duplo caminho: tesaurizou as aparências do mundo pela fotografia e as imagens pelo arquivo; o que a arte dos anos 1960-70 fez incansavelmente e que o impulso arquivístico evidenciou. Estar entre o

\footnotetext{
${ }^{8}$ No original: "The work in question is archival since it not only draws on informal archives but produces them as well, and does so in a way that underscores the nature of all archival materials as found yet constructed, factual yet fictive, public yet private."
} 
documento e a ficção é uma característica que marca a série Postcards from Brazil. "A tendência é que nossa produção, não importando a vertente, vire memória e documento de nossa época. Inclusive as fiç̧ões" (Barreto, 2018). E, "por mais paradoxal que possa parecer, o verdadeiro é uma produção mágica. (...) o documento precisa menos de semelhança, ou de exatidão, do que de conviç̧ão" (Rouillé, 2009: 62). O grande eixo para desarticular o absoluto do real na imagem fotográfica foi dado por Tisseron (2009), acima, mas é fortalecido por Rouillè (idem) no reconhecimento da magia inerente a toda veracidade, visto a passagem do regime de verdade da cultura oral (narra-se o verdadeiro) para a cultura escrita (lê-se o verdadeiro) e, por fim, para a cultura visual (vê-se o verdadeiro), geradora da crise da fotografia-documento: transforma-se ficção em verdade ou, ao menos, faz-se duvidar do verdadeiro.

Ao perceber essa mistura entre real e ficção intrínseca à fotografia, com base na produção visual de diversos artistas, Fontcuberta (1977) propõe o conceito de contravisão, retomado 20 anos mais tarde em seu livro $O$ Beijo de Judas: fotografia e verdade. Para o autor, a contradição "rompe a lógica interna da estrutura da linguagem verbal", o que em fotografia dar-se-ia pela contravisão, já que:

a atividade artística, isto é, a expressão criativa tem dois aspectos. De um lado, contribui para o desenvolvimento de uma certa plasticidade, fornecendo novas soluções linguísticas. Por outro lado, deve transcender o social, ou seja, deve responder às demandas sócio-políticas do ambiente em que o artista se desenvolve. (Fontcuberta, 1997: 28)

Os Postcards, ao mesmo tempo em que apresentam as demandas sócio-políticas do artista - assim como o idealizado por Oiticica (2009) ao falar da tomada de posição do artista nos problemas da sociedade -, denunciam e utilizam documentos factuais públicos, disponíveis a todos, para criar uma paisagem em que a realidade do falso é indistinguível e a desobliteração do amplo presente é levada a cabo. Justamente por recorrer a instrumentos relativos aos anos de privação da sociedade brasileira, Barreto expõe uma dupla operação entre a verdade e a ilusão: o país, que busca atrair turistas por meio da publicidade de suas paisagens naturais, não legenda essas imagens como cemitérios clandestinos.

A violência da ditadura militar brasileira também serviu de mote ao primeiro trabalho de Barreto, o fotolivro, Moscouzinho. A característica da publicação de mesclar imagens, de estar entre documento e ficção, é a mesma que marca a série Postcards from Brazil, exibindo elementos característicos do documental na medida em que pesquisa, apura o assunto e traz as informações nos postais. Por sua vez, ao recortar e escolher especificamente aquelas paisagens, o artista produz sua poética e propõe uma reflexão sobre um vasto campo sócio-político e um específico campo da violência. Barreto inicia 
seu processo criativo com base em pesquisas e cria uma obra que, como ele próprio afirma, mescla características do cinema e literatura (Barteló, 2018)

Eu costumo brincar que (minha fotografia) a fotografia, nasce da palavra, mas pensa que é cinema [...]

Acho que palavras são imagens. Vejo com naturalidade o ciclo que se faz entre palavras, conceitos, imagens, sons, símbolos, significados e as diversas maneiras possíveis de apresentação e assimilação do nosso trabalho. A fotografia é a maior plataforma do meu trabalho. Mas penso em fotografia (imagem) num sentido bem amplo. [...] Meu trabalho nasce da palavra, é fotografia, mas pensa que é cinema. Acho que quase tudo pode nos remeter à imagem. Acho que o cinema, como eu o imagino, explica bem a frase e a minha maneira de produzir. Tudo é feito com muitas camadas entrelaçadas. Até o momento das definições estéticas (estudo de cores, enquadramentos, composições), há diversos canais paralelos se somando, se alternando. Roteiro, palavra, sons, atuações, fotografia, ritmo, sequência. (Barreto, 2018)

"No verso das paisagens, no lugar em que o remetente do postal normalmente conta notícias e fala de saudade para amigos e parentes, estão escritos os depoimentos de testemunhas relatados à CNV" (Barteló, 2018: 51). Barreto resgata uma das épocas mais assombrosas da história do país e, por meio de sua produção artística, expõe a violência generalizada, do passado até o presente, praticada no Brasil. Usando documentos da CNV ele constrói um trabalho de investigação poética acerca dos dissabores de um país tão plural, rico e potente, amealhado sob os brasões e as insígnias da violência.

A noção de paisagem é relevante para falar dessa série de Barreto pois ela integra as preocupações do universo fotográfico a respeito da simultaneidade dos processos de troca, de transformação e de ambivalências, "tanto nos níveis concretos de violência, expropriação, colaboração, e coerção, quanto numa variedade dos níveis simbólicos e representacionais cuja relação com o concreto é raramente mimética ou transparente ${ }^{9 "}$ (Mitchell, 2002: 09). O fato é que a paisagem se transformou, e muito, desde que Niépce fotografou a vista de sua janela em Le Gras. No caso de Barreto, ela deve ser considerada por dois lados: o primeiro é o ponto de vista de Mitchell (2002), que a entende como um médium de expressão cultural e não um gênero da pintura ou das belas artes; o segundo diz respeito à compreensão da paisagem pela geografia de Milton Santos (1988: 21) "como tudo aquilo que nós vemos, o que nossa visão alcança"; a paisagem não é formada exclusivamente por "volumes, mas também por cores, movimentos, odores, sons, etc."

\footnotetext{
${ }^{9}$ No original: "At concrete levels of violence, expropriation, collaboration, and coercion, and at a variety of symbolic or representational levels whose relation to the concrete is rarely mimetic or transparent."
} 
Para a geografia há dois tipos de paisagem: a natural e a artificial. Barreto mistura as duas ao recortar as fotografias das quais se apropriou. Se a natureza oferece visões de cartões-postais do Brasil, Postcards as artificializa ao transformá-las em antipostais,em que o acúmulo dos acontecimentos históricos passa a integrar a paisagem de outrora. Afinal, "a paisagem é uma escrita sobre a outra, é um conjunto de objetos que têm idades diferentes, é uma herança de muitos diferentes momentos" (Santos, 1988: 22). Todavia, que diferença há na violência herdada dos anos da ditadura militar para os dias de hoje? Sob o aspecto da violência política, conforme discute Miguel (2015), ela continua ocultada. Tal aspecto evidencia Postcards como antipostais e antipaisagens, na medida em que dão visibilidade a esse oculto.

Esse é o paradoxo operado por Barreto: sendo a paisagem um objeto modificável e os cartões-postais dispositivos para a promoção turística, sua ação consiste em afirmar a imutabilidade da paisagem social brasileira e apresentar um país de vistas fraturadas: "um corpo de formas simbólicas capaz de ser invocado e reformulado a fim de expressar valores e significados ${ }^{10 "}$ (Mitchell, 2002: 14). Antipostais porque mostram um país cemiterial; antipaisagens porque em um cemitério a única mudança é a da matéria orgânica:

queria mostrar com este trabalho que as forças, práticas e até os mesmos elementos da ditadura ainda estão atuantes no Brasil de hoje. Não é um trabalho sobre o Brasil de 50 anos atrás, gostaria muito que fosse. Mostro uma das raízes do fascismo que desabrocha hoje com mais força. Mas nunca morreu, nunca foi combatido de verdade. O Postcards aponta direta e claramente para os golpistas de 64 e os de hoje. Está tudo às claras. (Barreto, 2018)

\section{Apontamentos sobre os antipostais}

A elaboração visual dos cartões-postais de Barreto é seriada, tal qual os assassinatos cometidos pela ditadura militar brasileira. Mesmo havendo depoimentos e testemunhos à CNV, não existem imagens das cenas descritas, exceto as paisagens tropicais produzidas pela Embratur. Há um ponto cego nesse capítulo da história, diferentemente do que ocorreu com o nazismo, por exemplo, em que a produção de álbuns fotográficos sobre os campos de concentração era uma tônica: mostrava-se tudo ${ }^{11}$.

A ausência de imagens das torturas é parte do buraco negro da memória da violência da ditadura [no Brasil]. A violência dos atos brutais do terrorismo de Estado acontecia ao mesmo tempo que a tentativa de se apagarem os seus rastros. (Seligmann-Silva, 2014: 14).

\footnotetext{
10 No original: "A body of symbolic forms capable of being invoked and reshaped to express meanings and values."

${ }^{11}$ Para saber mais sobre a fotografias nazi, veja-se Umbach (2015) e Weissman (2019).
} 
Uma das formas de apagar os rastros desse período foi a criação da Embratur, que tinha "por finalidade apoiar a formulação e coordenar a implementação da Política Nacional de Turismo, como fator de desenvolvimento social e econômico" (Embratur, 2011). Contudo, o interesse em divulgar as paisagens brasileiras visava atender ao objetivo de melhorar a imagem do Brasil no exterior, visto que a imprensa internacional havia tomado conhecimento das atrocidades produzidas no Florão da América - o que se deu, em grande medida, pela rede desenvolvida pela Arte Postal e pela ligação entre artistas de outros países sob regimes ditatoriais na América Latina. Assim, o governo cria a Embratur para camuflar os seus crimes, exaltando paisagens selvagens da terra brasilis - um modo de apelar ao desejo pelo exótico fortemente presente no imaginário ocidental $^{12}$. Portanto, às custas da tortura, o turismo no Brasil recebeu fortes incentivos. Durante o período da ditadura, o país era visto como um 'sub-império' dos Estados Unidos da América, semelhantemente ao que ocorre nos dias atuais ${ }^{13}$. Nos EUA, assim como no Brasil, o interesse político atual parece ser o da manutenção da violência estrutural, sob uma cultura e uma pedagogia do medo e da morte. Em 2018, no Brasil, registrou-se 175 mortes por dia, o mesmo número de países reunidos na Conferência das Nações Unidas sobre o Meio Ambiente e o Desenvolvimento, no Rio de Janeiro, em 1992. Naquele ano Rosangela Rennó produziu Atentado ao poder para denunciar os absurdos da violência no país sede da ECO-92. Absurdos visíveis em todas as imagens da série Postcards: há referência à quantidade de pessoas assassinadas e despejadas pelo poder do Estado naqueles locais, por meio das incisões produzidas em cada postal. Sim, é uma representação desses corpos, dessas memórias e desse terror; porém, não

\footnotetext{
${ }^{12} \mathrm{O}$ exótico e, portanto, o fora do padrão pode ser relacionado à criação do Arquivo das Índias quando a imagem do índio canibal fora construída com base no imaginário medieval europeu. $O$ exótico e a criação do bom e do mau selvagem, porque interligados, podem ser aprofundados por meio da análise de Joaquim Barriendos no artigo Regímenes de visualidad: emacipación y otredad desde América Latina (2011) ou no livro de Yobenj Aucardo Chicangana-Bayona intitulado Imagens de canibais selvagens do Novo Mundo: do maravilhoso medieval ao exótico colonial (séculos XV-XVII). O imaginário do exótico se expandiu também para a figura da mulher brasileira, como pode ser verificado tanto em Incríveis aventuras e estranhos infortúnios de Anthony Knivet (2007), de VivienKogut Lessa de Sá e Sheila Moura Hue, quanto na reportagem de Flávia Montavani sobre o apelo sexual nas campanhas da Embratur (Montvani, 2014, 27 de fevereiro).

${ }^{13}$ Para pontos específicos acerca das relações dos EUA com o Brasil durante a ditadura militar brasileira, propõe-se a leitura da matéria de Jennifer Ann Thomas e Emiliano Urbim (Thomas \& Urbim, 2018, 10 de outubro) e do artigo de Lorenna Burjack da Silveira (Silveira, 2009), que analisam as relações entres os dois países.
} 
apenas isto: a cicatriz deflagrada por Barreto lateja tanto quanto as lembranças dos sobreviventes, solicitadas diariamente pelo amplo presente.

Esse "amplo presente nos aponta para o planeta Terra, o lugar da condição da nossa sobrevivência individual e coletiva. [...] De um novo desvio em direção às coisas-domundo e ao cuidado delas". Além disso, "qualquer tipo de linguagem que seja capaz de desencadear uma experiência estética aparecerá como um terceiro amálgama entre presença e linguagem" (Gumbrecht, 2015: 133;26) ${ }^{14}$. Esse desencadeamento da experiência estética e a ciência sobre a condição de sobrevivência, levam-nos a aproximar os postais de Barreto à performance Palomo, de Berna Reale. Nela, a artista desfila montada em um cavalo pintado de vermelho, usando uniforme militar preto e focinheira logo nas primeiras horas do dia, por ruas sem movimento da cidade de Belém, no Pará. Reale propõe uma reflexão acerca do abuso de poder institucionalizado na sociedade.

A focinheira na personagem (representada por ela mesma) seria a forma de conter o animal/humano muito mais feroz do que o animal/bicho que ela monta? Não é ele, o animal/humano, que precisa ser contido? O vermelho do cavalo, por sua vez, simboliza o sangue que toda repressão militar deixa escorrer. (Barteló, 2018: 64).
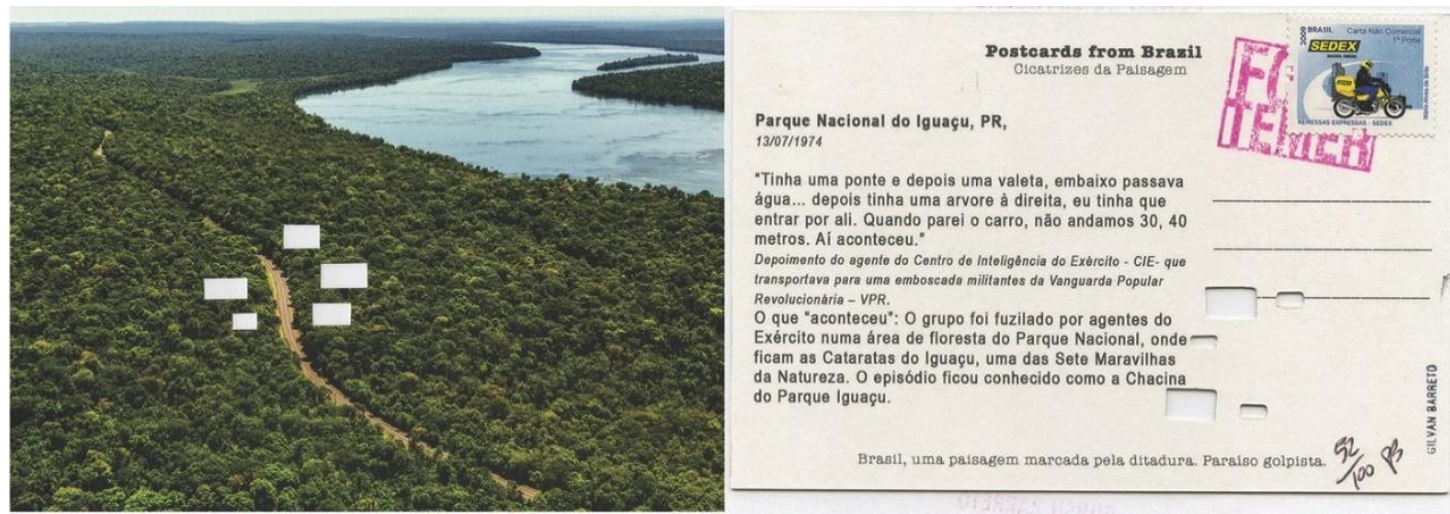

Figura 1. Gilvan Barreto, Postcards from Brazil, 2016.

Parque Nacional do Iguaçu, Paraná. Arquivo do artista.

Se em Palomo é o vermelho que simboliza o escorrimento da violência estrutural, em Barreto o símbolo está nas paisagens do Brasil. O Parque Nacional do Iguaçu, no Paraná (Figuras 1 e 2), onde ficam as Cataratas do Iguaçu, consideradas uma das sete

\footnotetext{
${ }^{14}$ Gumbrecht propõe seis tipos de amálgamas para pensar as relações, em nosso tempo, entre a presença e a linguagem: $1^{\circ}$ a linguagem, acima de tudo a linguagem falada enquanto realidade física, $2^{\circ}$ práticas básicas de filologia, 3ำ citado acima, 4ํa experiência mística e a linguagem do misticismo, 5ำ a linguagem sendo aberta ao mundo das coisas e 6ำ a literatura pode ser o lugar de epifania (Gumbrecht, 2015: 24-29). Grifos do próprio autor.
} 
maravilhas da natureza, foi escolhido como cenário para o fuzilamento de seis pessoas, das quais cinco militantes da Vanguarda Popular Revolucionária (VPR), "Onofre Pinto, os irmãos Daniel e Joel de Carvalho, José Lavecchia, Victor Ramos e o argentino Enrique Ruggia" (CNV, 2014: 61). De acordo com trecho do depoimento de um agente do Centro de Inteligência do Exército (CIE) à CNV, reproduzido no verso do postal, eles foram levados a cair em uma emboscada: "Tinha uma ponte e depois uma valeta, embaixo passava água... depois tinha uma árvore à direita, eu tinha que entrar por ali. Quando parei o carro, não andamos 30, 40 metros. Aí aconteceu”.

A chacina do Parque Iguaçu, como ficou conhecido o episódio, difere apenas em número de mortes em relação a outras chacinas ocorridas no Brasil, como as chacinas da Candelária, 1993, 8 mortos; de Vigário Geral, 1993, 21 mortos; do presídio de Urso Branco, em Rondônia, 2002, 27 mortos; do Cabula, em Salvador, 2015, 12 mortos; e o massacre do Carandiru, 1991, 111 mortos. Esse uso violento e arbitrário das estruturas do poder aparece também em trabalhos de outros artistas brasileiros, como Artur Barrio e Nuno Ramos. O primeiro, com suas Trouxas Ensanguentadas ${ }^{15}$ (1970), dispostas às margens do Ribeirão Arrudas, em Belo Horizonte, nas quais era possível ver o vermelho do sangue dos pedaços de animais ensacados. Assim como Barreto, Barrio estava preocupado em denunciar a violência da ditadura.

Nuno Ramos, por sua vez, produz a instalação 111 em homenagem aos detentos assassinados no massacre do Carandiru, usando um texto que já tinha usado na instalação Aranha e que volta a usar no livro Cujo:

quis me mover mas não me movi. Eu quis. Estava debruçado, morto desde o início. A grama alta quase não me deixava ver. Estava morto desde o comecinho. Eu quis o medo mas não o pude ter. Estava deitado, debruçado bem morto. Quis ver o primeiro bicho e a raiz da primeira planta. A grama alta não me deixava ver. Quis ficar acordado mas dormi. (Ramos, 1993, p.27)

Ramos não se propõe a discutir a ditadura, mas sim a força policial frequentemente empregada e sancionada pelas estruturas do poder existentes no Brasil. Todos os três exploram a necessidade de rever o lugar que se dá à vida, à morte, ao corpo do outro. A repetição dos massacres faz pensar sobre a crítica ao tempo histórico levantada por Gumbrecht (2015), quando este fala do cronotopo padrão adotado pelo sujeito cartesiano: aquele que se sente em um progresso temporal linear, no qual é possível se movimentar no tempo, deixando para trás o passado em busca de um futuro prenhe de

\footnotetext{
${ }^{15}$ As Trouxas Ensanguentadas (T.E) do artista luso-brasileiro Barrio, foram produzidas pela primeira vez para o Salão Bússola, no MAM-RJ, em 1969 e, uma segunda vez, abandonadas pelas ruas da cidade do Rio de Janeiro. Em maio de 1970, ele repete a ação em Belo Horizonte. As T.E eram feitas de sangue, carne, ossos, barro, espuma de borracha, pano, cordas, facas, sacos, cinzel e outros materiais.
} 
possibilidades, em que o presente é meramente um breve momento de transição. Dentro do que o autor chama de amplo presente, essa visão cartesiana é impossível. "Hoje sentimos cada vez mais que o nosso presente foi expandido, pois agora está rodeado por um futuro que não conseguimos mais ver, ter acesso ou escolher, e por um passado que não conseguimos deixar para trás" (Gumbrecht, 2015: 48).

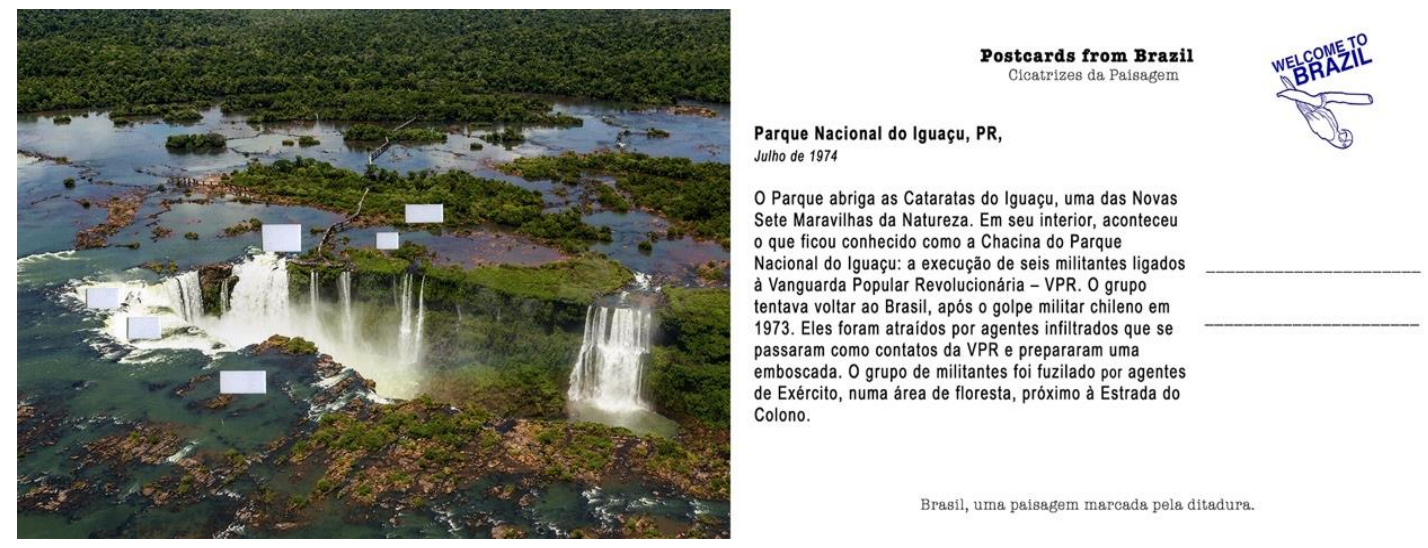

Figura 2. Gilvan Barreto, Postcards from Brazil, 2016. Parque Nacional do Iguaçu 1, Paraná I. Arquivo do artista.

Para Gumbrecht, nosso amplo presente tem um cronotopo cujo nome é inexistente, mas para o qual é possível pensar a partir de quatro oscilações: uma primeira relacionada às crises econômicas e, portanto, ao "realmente real"; uma segunda que oscila entre a responsabilidade sobre os corpos individuais atribuída ao Estado e a livre fruição do corpo como jogo de experimentação; uma terceira relacionada ao poder "como violência que passou da esfera da ação e do efeito imediatos para o reino do potencial bruto" e com a criação de um mundo ilusório destituído desse poder e dessa violência; e, por fim, uma oscilação no modo de pensar, um pensamento modelado pelo espaço da comunicação em rede, que faz de si uma mera circulação, um "processo de mera passagem de pensa-mentos" (Gumbrecht, 2015: 133, 135 e 138). Em resumo, a questão de Gumbrecht, presente nos Postacards, reside em indagar o que fazer com esse conhecimento sobre o passado que amplia o presente e torna o futuro uma ameaça imediata, sem porvir.

Essas oscilações podem, também, ser vistas no trabalho de Rosana Paulino, $A$ permanência das estruturas (2017), no qual ela reproduz sobre tecido a planta baixa de um navio negreiro com a disposição dos corpos dos escravos em seu interior, e nas fotografias de pessoas negras de Auguste Stahl (1828-1877), feitas por encomenda do criacionista Louis Agassiz (1807-1873), para tentar comprovar a inferioridade da raça 
negra em relação à branca ${ }^{16}$. O trabalho de Paulino parece mostrar a impossibilidade de um futuro sem mortes, sem racismo estrutural e epistêmico. Entender esse campo de oscilações tem sido o propósito de produções artísticas brasileiras, com maior intensidade desde o período ditatorial. Paulino e Barreto participam de modo efetivo e tenaz denunciando, com suas produções poéticas, essa permanência das estruturas de violência, sobretudo porque ela "só pode ter fim se o colonizado se dispuser a pôr termo à história da colonização" (Fanon, 1968: 38) e, especificamente em Barreto, pôr fim ao fascismo crescente que atinge em cheio a produção da arte no Brasil hoje em dia.
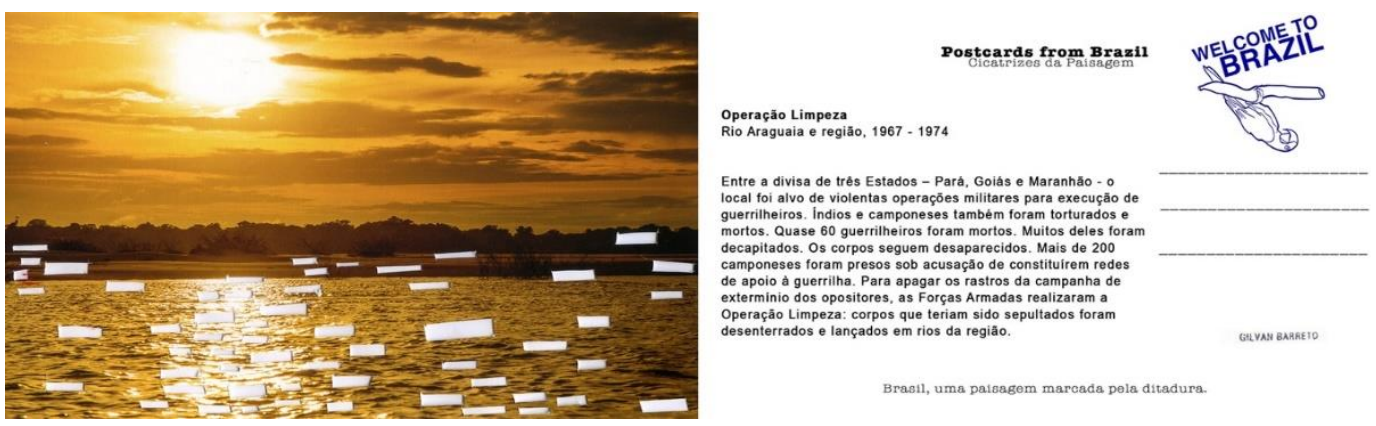

Figura 3. Gilvan Barreto, Postcards from Brazil, 2016. Araguaia, Centro-Oeste I. Arquivo do artista.

Em relação aos artistas, a coisa ainda pode piorar. Mas acho que o grande interesse deles é a censura, os cortes das políticas culturais, dos editais. Querem nos ver tristes, sufocados, fragilizados. Tentam neutralizar nossos discursos e vozes. Mas a arte também opera nas brechas. Silenciar o poder que a arte tem de transformar, imaginar novos mundos, de quebrar normas, questionar, desobedecer. Isso é tão poderoso que a arte, cultura e educação foram os primeiros alvos dos golpistas. Censura, perseguição, intimidação. Estamos vivenciando o tempo da ignorância como política de Estado. O incremento artificial, pobreza intelectual, no sentido que é um movimento planejado, premeditado. Mentiras, conluio, culto ao ódio, intolerância e o moralismo como principal bandeira. Tudo isso nos liga à ditadura. (Barreto, 2018)

A região do rio Araguaia (onde ocorreu a Guerrilha do Araguaia, movimento coordenado pelo Partido Comunista do Brasil (PCdoB), entre as décadas de 1960 e 1970, com propósito de iniciar, pela área rural, uma revolução socialista inspirada nas experiências de Cuba e da China), foi cenário da barbárie ditatorial (Figuras 3 e 4). Ali os militares aplicaram, crua e cruelmente, sua força e poder, chegando a usar napalm - conjunto de líquidos inflamáveis à base de gasolina gelificada, utilizado como armamento militar em guerras. Em depoimento à CNV (2014: 710), uma moradora da região contou: "Soldado

\footnotetext{
${ }^{16}$ Agassiz e Stahl passaram pelo Brasil, o primeiro vindo ao país no comando da Expedição Thayer, de 1865 a 1866, e o segundo aqui permanecendo no período de 1853 a 1875. A expedição tinha como objetivo realizar um estudo dos tipos raciais brasileiros do Rio de Janeiro e da Amazônia.
} 
eu não vi nenhum morto. Sinceramente eu não vi. Agora guerrilheiro eu vi. Eu vi um saco de cabeças." As cicatrizes evidenciadas por Barreto revelam 56 guerrilheiros mortos, entre índios e camponeses, muitos dos quais decapitados e lançados em afluentes do rio.

O grupo que originou o PCdoB, por sua vez, acreditava ser impossível um caminho completamente pacífico para o socialismo. (...) Em determinado momento do processo de reformas democratizantes e anti-imperialistas, as forças da reação usariam de violência, impondo aos comunistas o caminho da resistência armada em nome do processo revolucionário (CNV, 2014: 681)
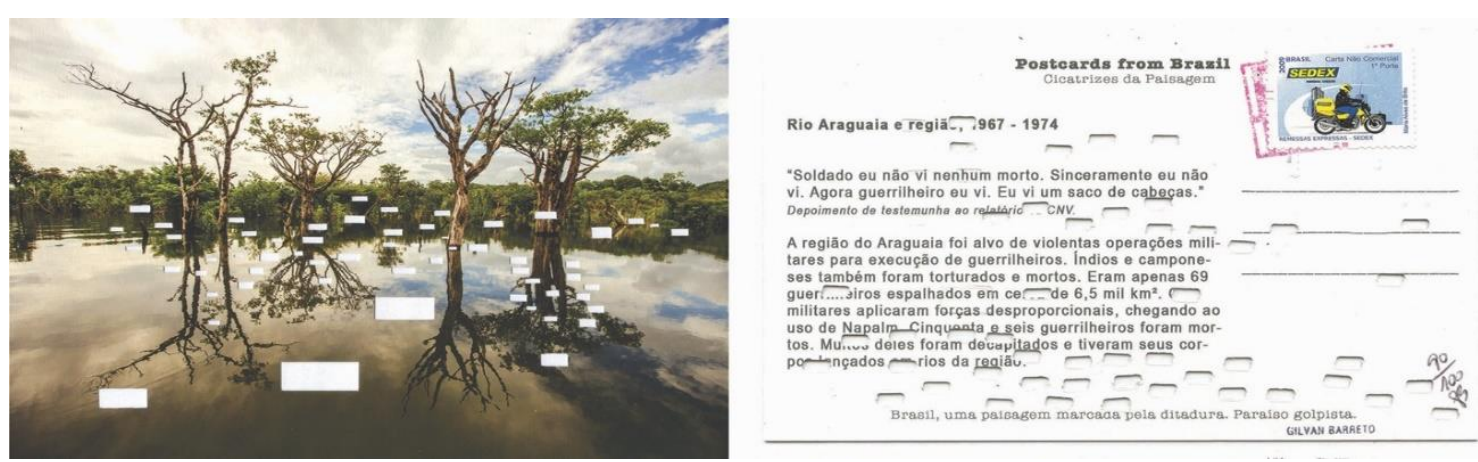

Figura 4. Gilvan Barreto, Postcards from Brazil, 2016. Araguaia, Centro-Oeste 1. Arquivo do

Relato interessante para se pensar a afirmação de Fanon (1968: 56), de que a violência "é a intuição que têm as massas de que sua libertação deve efetuar-se, e só pode efetuar-se pela força". Fanon demonstra como o colonizado nutria e vivia um ódio e uma inveja do colonizador por inúmeros fatores elencados ao longo de seu texto, mas, principalmente, porque o mundo colonial impossibilitava ao subalterno uma existência digna de ser vivida. Impossibilidade dada pela ideia de representação, tal qual discutida por Spivak (2010: 31-38), em seus dois aspectos, tanto no direcionado à política (falar por) quanto à arte e à filosofia (representar). Nesse sentido, restava unicamente uma forma de combate: usar da mesma, ou maior, violência contra o colono. Sem armas letais, sem o uso de uma violência aberta, Barreto encontra um modus operandi específico para resistir e denunciar as atrocidades cada vez mais recorrentes de um governo que preza pela manutenção das estruturas de violência. 

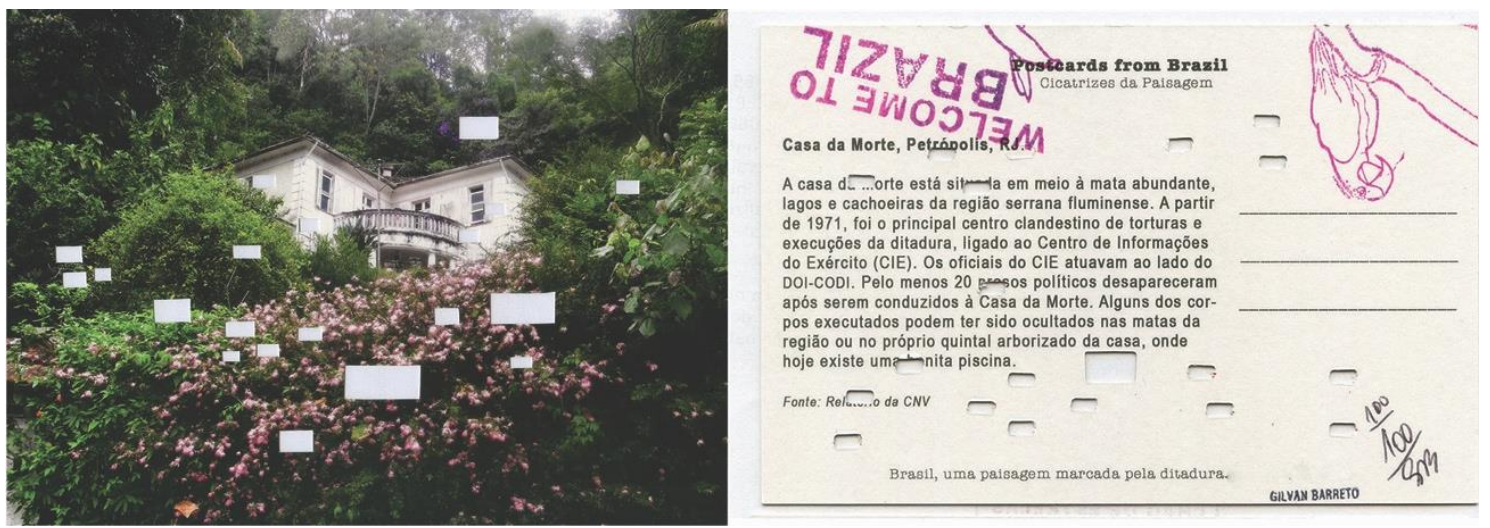

Figura 5. Gilvan Barreto, Postcards from Brazil, 2016.Casa da Morte, Rio. Arquivo do artista.

Postcards from Brazil: cicatrizes da paisagem coloca, literalmente, o dedo na ferida, assim como a música de Criolo e Emicida (2013):

Porque a justiça deles, só vai em cima de quem usa chinelo

E é vítima, agressão de farda é legítima

Barracos no chão, enquanto chove

Meus heróis também morreram de overdose,

De violência, sob coturnos de quem dita decência

Homens de farda são maus, era do caos,

Frios como halls, engatilha e plau!

Carniceiros ganham prêmios,

$\mathrm{Na}$ terra onde bebês, respiram gás lacrimogênio.

Essa tem sido uma vertente da atmosfera brasileira desde sua existência como país: "engatilha e plau!". Mas, para além dessa revelação de dor, qual conhecimento as imagens de Barreto reclamam? "Cada vez que depomos nosso olhar sobre uma imagem, deveríamos pensar nas condições que impediram sua destruição, sua desaparição" (Didi-Huberman, 2012: 210). E pensar porque as imagens da Embratur não foram destruídas é parte da oscilação de nosso amplo presente, da necessidade de reorganizar e reprocessar esse passado tão vívido do turismo, da exploração e da violência como moeda ativa.

Ou, como cantou Raul Seixas (1980), "a solução é alugar o Brasil”. Alugar para o "gringo", cujo dólar pagará não só o mingau, mas ensinará os analfabetos a falar inglês, um certo tupinglish, orquestrado como uma língua universal. Daí Barreto trazer o título de seu trabalho em inglês:

A Embratur foi criada pela ditadura com a intenção de melhorar a imagem deste Estado terrorista, assassino. Um paraíso "pra inglês ver", como diz o ditado. Precisava continuar na linha deles. Penso também nessa coisa meio jeca nossa de tentar falar inglês (e ignorar o espanhol do continente ao qual pertencemos). (Barreto, 2018) 
Barreto recupera o espírito crítico de Seixas no que diz respeito às relações políticas do Brasil com outros países, especialmente os EUA. Trazer à tona essas camadas camufladas é dar a ver o real pela sua ficcionalização, pensá-lo para o retirar da obliteração e, ao mesmo tempo, provocar conhecer a dimensão inteira dos acontecimentos. Portanto, desvelar os corpos escondidos, as histórias encobertas respondem ao anseio de devolver ao país sua própria auto imagem, mesmo que dura e sangrenta. E, se não há como exaurir o valor de uma paisagem, conforme salienta Mitchell (2002: 15), porque ela expressa também seu significado para funcionar como instrumento de comunicação entre as pessoas, também não há como extinguir as reinterepretações e reapropriações do passado para melhor conhecê-lo no presente.

Em 1971, em Petrópolis, região serrana do Rio de Janeiro, localizada em meio a uma mata, lagos e cachoeiras, funcionou a Casa da Morte. O imóvel foi o principal local clandestino de torturas e execuções da ditadura, mantido e organizado pelo Centro de Informações do Exército (CIE) em apoio ao DOI-CODI, também conhecido por 'Codão'. O texto desse postal, a fotografia da Casa da Morte (Figura 5), narra as características de onde a casa estava implantada e o desaparecimento de cerca de 20 presos políticos. $\mathrm{Na}$ época, os corpos das pessoas ali executadas eram ocultados na mata da região e no quintal da casa. A única sobrevivente, Inês Etienne Romeu, foi uma das peças fundamentais para a compreensão das atrocidades cometidas no local.
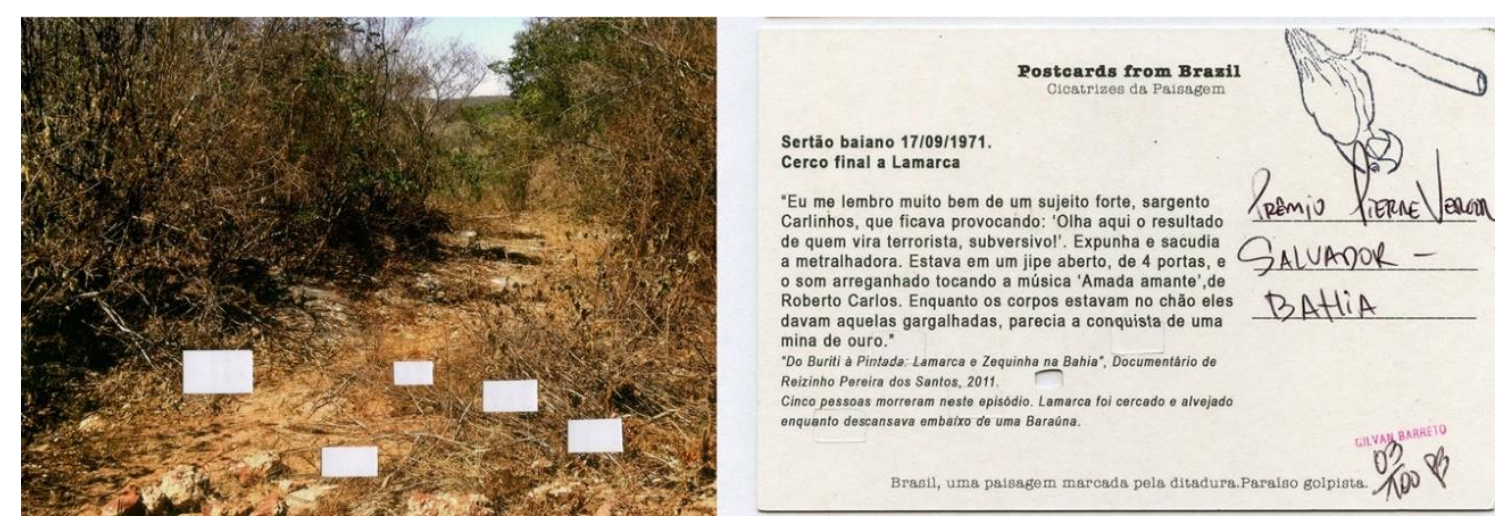

Figura 6. Gilvan Barreto, Postcards from Brazil, 2016. Bahia I. Arquivo do artista 
Conforme descreve o texto do postal, a execução de cinco pessoas na paisagem do sertão baiano se deu ao som da música Amada Amante, cantada por Roberto Carlos, ícone do movimento Jovem Guarda e inspiração para a juventude brasileira da época. Tratava-se do cerco final a Carlos Lamarca, militar desertor, que se tornou um dos principais líderes da luta armada contra a ditadura militar. O postal de Barreto (Figura 6) reconta esse pedaço da história a partir de um trecho do documentário Do Buriti à Pintada: Lamarca e Zequinha na Bahia. A fotografia é um misto de aridez e vida. Da primeira, tem-se a secura da saliva, o tremor das mãos, o aceleramento dos batimentos cardíacos atrelados aos passos-tropeços nas pedras, provocados pelos empurrões dos militares; um caminho interrompido pela perspectiva da imagem em alusão à interrupção da segunda. Desta, fica a esperança de umidade, de florescimento de um presentefuturo de passado conhecido.

A história de uma única cicatriz na paisagem do rio Jacuí, no Rio Grande do Sul, ressalta a importância de seu evento (Figura 7). O verso da imagem narra um trecho da última carta de Manoel Raimundo Soares, um dos líderes do Movimento Legalista. Ele queria restituir o cargo ao presidente João Goulart, deposto pelos militares. No documento, de 25 de junho de 1965 - um dos anos mais violentos da ditadura, quando foi promulgado o Ato Institucional número 5, o Al-5, medida que intensificou a repressão -, fica claro o posicionamento político de Manoel frente à repressão. Por ter sido encontrado com as mãos e pés amarrados às costas, o episódio ficou conhecido como "o caso do sargento das mãos amarradas".
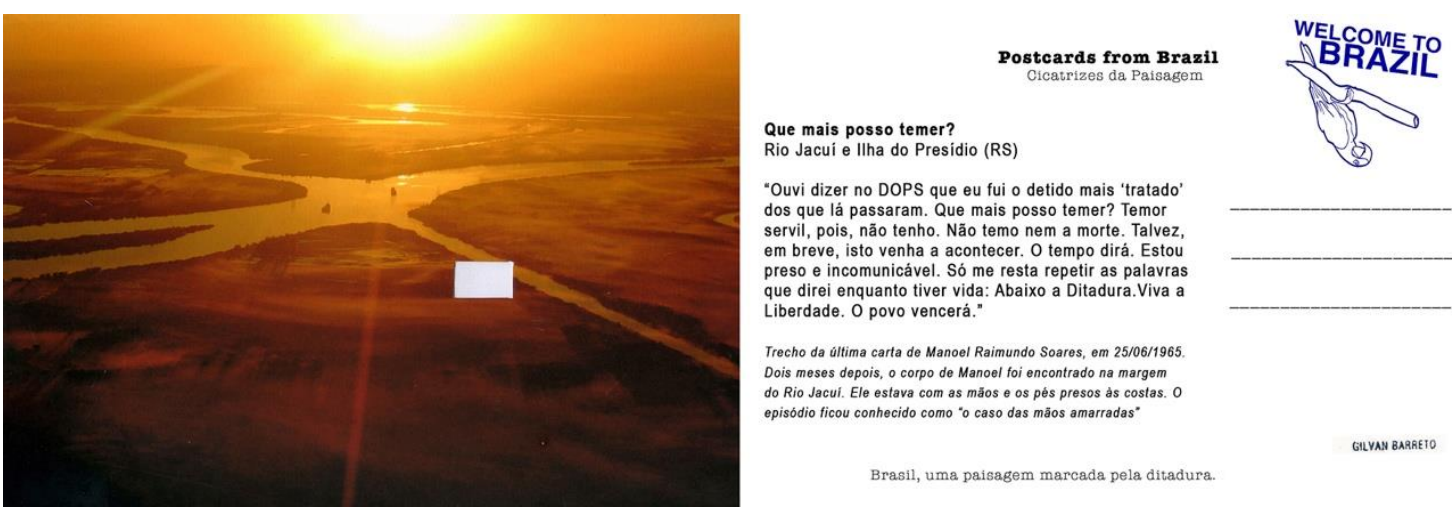

Figura 7.Gilvan Barreto, Postcards from Brazil, 2016. Rio Grande do Sul I. Arquivo do artista.

Ouvi dizer no Dops que eu fui o detido mais 'tratado' dos que lá passaram. Que mais posso temer? Temor servil, pois, não tenho. Não temo nem a morte. Talvez, em breve, isto venha acontecer. O tempo dirá. [...] Estou preso e incomunicável [...]. Só me resta repetir as palavras que direi enquanto tiver vida: Abaixo a Ditadura. Viva a Liberdade. O povo vencerá. (CNV, 2014: 601, 603 e 604)

A imensidão da paisagem, reforçada pelo enquadramento aéreo da fotografia, pela força da união dos braços d'água e pelo calor do amarelo-quente-alaranjado da luz solar, 
destaca o corpo de Manoel para desobliterar o passado e apresentar a urgência de se pensar a vida do presente. Por ser um único corpo, uma única vida, há certa identificação daquele que vê a imagem. É possível se colocar no lugar de Manoel, encaixar-se no recorte, diminuindo o próprio corpo, na imaginação. De outro modo, elabora-se uma imagem cuja exuberância deve ser revisitada ao som das palavras de Ribeiro, já citadas no início do texto, de que a tarefa das novas gerações é tomar o país em suas mãos. A insularidade desse corpo mostra sim a marca de um "Brasil, uma paisagem marcada pela ditadura. Paraíso golpista" (Barreto, 2018). Apesar disso, esse único corpo-recorte rasga a paisagem edênica e nos convida a elaborar, juntos, nossos afluentes.

\section{Considerações finais}

Os postais de Barreto estampam as atrocidades cometidas pelo regime da ditadura militar; dão a ver as cicatrizes de uma paisagem que persiste na vida do presente. Afinal, mostram tanto "a beleza que esconde o terror. Um paraíso traiçoeiro e letal" (Barreto, 2018) quanto apresentam essas cenas como em um espelho retrovisor, em que a paisagem pode estar mais próxima do que aparenta (Mitchell, 2002: 21). Essa proximidade pode ser compreendida pelas discussões de Mbembe $(2017,2014)$, nas quais a necropolítica cria um sujeito padrão, fundado na modernidade/colonialidade: branco, racional, livre, autônomo e capaz de autoconhecimento, que ainda existe e que ainda relega o subalterno à inferioridade. Contudo, ao falar da crítica da razão negra, o autor demonstra o quanto o autogoverno e o autoconhecimento do negro abrem para a tomada de consciência em relação à descolonização do pensamento, rompendo com a violência epistêmica produzida ao longo dos séculos.

Neste sentido, nota-se nos antipostais de Barreto esse empenho em se autogovernar política, histórica e culturalmente. As imagens se tornam antipostais ao exibirem um florão apodrecido, uma história embebida em poças de sangue fresco, uma sobrevida de um país doente. São imagens que, quando enviadas pelos Correios, tensionam os campos do júbilo e do terror e a dureza de se deparar com a dissolução das fronteiras "entre resistência e suicídio, sacrifício e redenção, martírio e liberdade" (Mbembe, 2016: 146). Além disso, para descortinar

o assombramento, para milhões de pessoas apanhadas nas redes da dominação de raça, de verem funcionar os seus corpos e pensamentos a partir de fora, e de terem sido transformadas em espectadores de qualquer coisa que era e não era a sua própria vida. (Mbembe, 2014: 19)

A contradição presente na ideia de um paraíso letal desvela, como verbo transitivo direto (contradizer), todos os cidadãos cuja luta diária se dá no embate contra a máquina do 
necropoder e, como verbo transitivo direto e pronominal (contradizer-se), a crueldade do Brasil sob a forma de um campo de morte, um grande cemitério a céu aberto iniciado com o projeto cristão colonial de conversão do gentil - intenção ainda existente no cenário político atual ${ }^{17}$.

Pelo lado poético, o fogo que faz arder é o mesmo que anima a intencionalidade artística:

arde pelo resplendor, isto é, pela possibilidade visual aberta de sua própria consumação: verdade valiosa mas passageira, [...] Arde por seu intempestivo movimento, incapaz como é de deter-se no caminho [...] Arde por sua audácia, quando faz com todo retrocesso, toda retirada sejam impossíveis[...] Arde pela dor da qual provém e que procura todo aquele que dedica tempo para que se importe. Finalmente, arde pela memória, quer dizer que de todo modo arde, quando já não é mais que cinza: uma forma de dizer sua essencial vocação para a sobrevivência, apesar de tudo. (Didi-Huberman, 2012: 216)

Arde porque precisa latejar para manter a brasa como alimento, porque é essa brasa que será possível arremessar, feito um meteoro em queda na atmosfera, para iluminar as cicatrizes desta vulgar paisagem brasileira: a morte. A potência dos antipostais de Gilvan Barreto é proporcional aos horrores que apresentam e deflagram o avesso da paisagem na dor da vida no presente, sem mais nem menos. Uma dor que conduz à ação, e não mais à letargia. Uma vida no presente umedecida pela certeza do autoconhecimento e, por conseguinte, pela negação absoluta e irrestrita das tentativas de continuidade de produção de violência. Longe de ser uma lamentação, Postcards from Brazil sustenta a necessidade de recolocar as dobradiças adequadas no quadro histórico brasileiro e, mais, de oferecer ao povo - entendido como categoria subalterna desde os primórdios do capitalismo -, a autonomia, a liberdade, o autoconhecimento e o autogoverno necessários para desfazer a manutenção da violência estrutural e epistêmica ainda persistentes.

\section{Agradecimentos}

A Gilvan Barreto pela gentileza e generosidade em nos conceder a entrevista neste artigo, por ter sido tão solícito em todos os momentos em que foi procurado e, também, pela paciência em relação a nosso processo criativo.

\footnotetext{
17 Para saber mais sobre a ligação do atual governo brasileiro com o evangelismo, veja-se Almeida (2019).
} 


\section{Referências bibliográficas}

Almeida, R. De (2019). Bolsonaro Presidente: conservadorismo, evangelismo e a crise brasileira. Novos Estudos Cebrap, 38 (1), 185-213. doi:

$10.25091 / \mathrm{s} 01013300201900010010$

Barba, M D \&Wentzel, M (2016, 20 de abril). Discurso de Bolsonaro deixa ativistas 'estarrecidos' e leva OAB a pedir sua cassação. BBC News Brasil. Consultado em: https://www.bbc.com/portuguese/noticias/2016/04/160415_bolsonaro_ongs_oab_mdb.

Barteló, C (2018). Fotografias que contam histórias: uma análise das narrativas nas séries Não minta para mim (Paulo Coqueiro), Postcards from Brazil (Gilvan Barreto) e Transparências de lar (Ilana Bar). Dissertação de Mestrado. Universidade Federal da Bahia, Salvador, Brasil.

Berger, C \& Santone, J (2016). Documentation as Art Pratice in the 1960s. Visual Resources, v.3-4, n.32, 201-209. doi: 10.1080/01973762.2016.1241030

Buckland, M (2013) Document Theory: an introduction,in M. Willer, A. J. Gilliland \& Tomic, M (Eds.). Records, Archives and Memory: Selected Papers from the Conference and School on Records, Archives and Memory Studies. Zadar: Universidade de Zadar. Consultado em:http://people.ischool.berkeley.edu/ buckland/zadardoctheory.pdf.

Caminha, P. V. de (1500). A carta de Pero Vaz de Caminha. Rio de Janeiro: Fundação Biblioteca Nacional. Consultado em:http://objdigital.bn.br/Acervo_Digital/Livros_eletronicos/carta.pdf.

Carliman, C (2013). Arte brasileira na ditadura militar: Antonio Manoel, Artur Barrio e Cildo Meirelles. Rio de Janeiro: Reptil.

Correia, M. da L (2013). Intermitências na cultura visual contemporânea: o postal ilustrado e a imagem recreativa. Tese de Doutoramento, Universidade do Minho, Lisboa, Portugal. Universitè Paris Descartes, Paris, França. Consultado em: https://repositorium.sdum.uminho.pt/handle/1822/29216?locale $=\mathrm{fr}$

Criolo \& Emicida (2013). Dedo na ferida [música]. Brasil: Oloko Records, Laboratório Fantasma.

Embratur (2011). Regimento Interno. Consultado em:http://www.embratur.gov.br/piembraturew/opencms/galerias/Downloads/Regimento _interno/RIfinal-formatado-2011.v2-1.pdf.

Fanon, F (1968). Os Condenados Da Terra. Rio de Janeiro: Civilização Brasileira.

Fontcuberta, J (1996). Vidência e evidência. Imagens, v.1, n.7, 08-15.

Fontcuberta, J (1977). La subversion photographique de la réalité. The Village Cry Magazine, v.7, n.1. Basel, Switzerland.

Fontcuberta, J (2010). O beijo de Judas - fotografia e verdade. GustavoGili: Barcelona.

Foster, H (2004). An Archival Impulse. October, v.1, n.110, 3-22. Consultado em: https://www.jstor.org/stable/3397555. 
Heidar, D., Rossi, M.; Oliveira, R. \& Bianchi, P. (2019, 18 de outubro). Às vésperas do afastamento de Dilma, Lava Jato rejeitou delação que prenderia Temer em 2019. El País. Consultado em:

https://brasil.elpais.com/brasil/2019/09/30/economia/1569857428_539313.html

Kossoy, B (2016). Decifrando a realidade interior das imagens do passado,In Kossoy, B, Realidades e ficções na trama fotográfica (pp. 61-126). São Paulo: Ateliê Editorial.

Lopes, A (2014). A arte postal durante a ditadura militar e a ideia de arquivo, in A. Medeiros, L. G. Pimentel, I. Hamoy \& Y.-A. Froner (eds.). Anais do 23ํe encontro da Associação Nacional de Pesquisadores em Artes Plásticas, Ecossistemas Artísticos, 15 a 19 de setembro de 2014, Belo Horizonte. (pp. 2659 - 2674). Belo Horizonte: ANPAP. Consultado em:

http://www.anpap.org.br/anais/2014/ANAIS/simposios/simposio07/Almerinda\%20da\%2 0Silva\%20Lopes.pdf

Mbembe, A (2017). Necropolítica. Arte \& Ensaios, 2(32), 122-151. Consultado em https://revistas.ufrj.br/index.php/ae/article/view/8993/7169.

Mbembe, A (2014). Crítica da razão negra. Lisboa: Antígona.

Miguel, L F (2015). Violência e política. Revista Brasileira de Ciências Sociais, 30(88), 29-44. Consultado em:http://www.scielo.br/pdf/rbcsoc/v30n88/0102-6909-rbcsoc-3088-0029.pdf.

Mitchell, W J T (2002). Imperial Landscape, in Mitchell, W J T. Landscape and Power (pp.5-34). Londres: The University of Chicago Press.

Montvani, F. (2014, 27 de fevereiro) No passado, Brasil já teve material oficial de turismo com apelo sexual. G1 Globo. Consultado em: http://g1.globo.com/turismo-eviagem/noticia/2014/02/no-passado-brasil-ja-teve-material-oficial-de-turismo-comapelo-sexual.html.

Oiticica, H (2009). Esquema geral da nova objetividade, in Ferreira, G. \& Cotrim, C. Escritos de Artistas. Anos 60/70 (pp.154-168). Rio de Janeiro: Zahar.

Quijano, A (2005). Colonialidade do poder, eurocentrismo e América Latina, in Lander, E. (ed.). A colonialidade do saber: eurocentrismo e ciências sociais (pp.227-278). Buenos Aires: Clacso.

Pessoa, G S (2018, 1 de outubro). Toffoli diz que hoje prefere chamar golpe militar de 'movimento de 1964'. Folha de São Paulo. Consultado em:

https://www1.folha.uol.com.br/poder/2018/10/toffoli-diz-que-hoje-prefere-chamarditadura-militar-de-movimento-de-1964.shtml.

Pauluze, T \& Nogueira, I (2019, 8 de abril). Exército dispara 80 tiros em carro de família no Rio e mata músico. Folha de São Paulo - Cotidiano. Consultado em: https://www1.folha.uol.com.br/cotidiano/2019/04/militares-do-exercito-matam-musicoem-abordagem-na-zona-oeste-do-rio.shtml

Ramos, N. (1993). Cujo. São Paulo: Editora 34.

Rancière, J (2005). A partilha do sensível. São Paulo: Editora 34 e EXO experimental org. 
Ribeiro, D (2010). O povo brasileiro. São Paulo: Companhia das Letras.

Rouillé, A (2009). Entre documento e expressão, in Rouillé, A. A fotografia entre documento e arte contemporânea. São Paulo: Senac.

Ruffato, L. (2016, 1 de setembro). O golpe contra Dilma Rousseff. El País. Consultado em: https://brasil.elpais.com/brasil/2016/08/31/opinion/1472650538_750062.html

Schedler, L (2016). Arte (Postal) como processo. Palíndromo, 8(15), 20-41.

Consultado em:

http://www.revistas.udesc.br/index.php/palindromo/article/viewFile/7733/6311.

Seixas, R (1980). Aluga-se. [música] Rio de Janeiro: Columbia Records.

Silveira, L. B. Da (2009) Estados Unidos e o Golpe de 1964: suporte logístico, bélico, financeiro e a concessão de exílio politico. II Seminário de Pesquisa da Pós-

Graduação em História UFG/UCG. Goiânia: Universidade Federal de Goiás.

Consultado em: https://pos.historia.ufg.br/up/113/o/IISPHist09_LorennaBurlveira.pdf.

Spivak, G (2010). Pode o subalterno falar?. Belo Horizonte: Editora UFMG.

Stiegler, B (2007). Reflexões (não) contemporâneas. Chapecó: Argos.

Thomas, J. A. \& Urbim, E. (2018, 10 de outubro). A verdadeira participação dos EUA no golpe de 64. Super Interessante. Consultado em:

https://super.abril.com.br/especiais/a-verdadeira-participacao-dos-eua-no-golpe-de$64 /$.

Tisseron, S (2009). Sonho, memória alucinação. Elogio da realidade contaminada, in E. Chiodetto (ed.). A invenção de um mundo: coleção da Maison Européenne de la Photographie (pp.136-140). São Paulo: Itaú Cultural.

Umbach, M. (2015). Selfhood, Place, and Ideology in German Photo Albums, 19331945. Central European History, v.48, ํ3, 335-365. doi: 10.1017/S0008938915000783

Weissman, G. (2019). On Photographing Nazi Camps. Shofar. v. 37, n. 1, 9-40.

Welch, C. (1995). Eternal Network. A Mail Art Anthology. Calgary: University of Calgary Press.

Fábio Gatti é artista visual, Doutor em Artes pela Unicamp e Mestre em Artes Visuais pela Escola de Belas Artes da UFBA, onde é professor colaborador no Programa de Pós-graduação em Artes Visuais desde 2014. Especialista em Fotografia e em História e Teorias da Arte, ambas pela Universidade Estadual de Londrina. Debruça-se especialmente sobre as inquietações oriundas do fazer artístico, da fotografia e dos processos de criação em artes visuais. Em 2018, organizou o livro eletrônico Futuro fora do tempo: poética, foto-grafia e incertezas. Em 2017, junto com 
Rosa Gabriella de Castro Gonçalves, produziu o livro A operação artística: filosofia, desenho, fotografia e processos de criação.

凹 bartelo.cassandra@gmail.com

Cassandra Barteló é jornalista, formada pela Faculdade de Comunicação da UFBA (1995). Mestra em Cul-tura e Sociedade, na linha de pesquisa Cultura e Arte, pelo IHAC/ UFBA (2018), com especializações em RP pela UNEB (2005) e Jornalismo e Convergência Midiática pela FSBA (2011). É autora da monografia A expressão de personagens na fotografia: O Olhar de Vânia Toledo, e da dissertação de mestrado Fotografias que contam histórias - Uma análise das narrativas nas séries Não minta para mim (Paulo Coqueiro), Pos-tcards from Brazil (Gilvan Barreto) e Transparências de lar (Ilana Bar). Mais recente-mente, tem enveredado pela prática da fotografia artística, desenvolvendo trabalhos autorais e participando em exposições coletivas. Atualmente, trabalha como editora do Grupo A Tarde.

凶gatti_f@yahoo.com.br 